\title{
CSR DISCLOSURE OF FINANCIAL EUROPEAN COMPANIES WITHIN INTEGRATED REPORTS
}

\author{
Bianca Raluca B̆̈DIT⿱OIU ${ }^{1}$ \\ Alexandru BUGLEA ${ }^{2}$ \\ Diana Corina GLIGOR-CIMPOIERU ${ }^{3}$ \\ Valentin Partenie MUNTEANU 4
}

DOI: $10.24818 / \mathrm{IMC} / 2020 / 05.02$

\begin{abstract}
The numerous, disconnected and static communication strategies of companies changed lately into a more comprehensive approach to corporate reporting in order to present corporate value in dynamics. Among the numerous benefits of this new way of reporting, entitled integrated reporting, we can identify: improving the quality of the information for capital providers and investors or other corporate stakeholders, enhancing accountability and stewardship of capitals, assisting integrated thinking, the decision process and corporate actions, providing better financial stability and sustainability. Our paper comprises a qualitative analysis of 16 integrated reports of banking and insurances European financial companies, from the Integrated Reporting Example Database, while reviewing their integrated reports with respect to their CSR (Corporate Social Responsibility) disclosures. Taking into account previous literature models, this paper analyses the information revealed within integrated reports, simultaneously concerning the traditional and strategic approach of CSR. The methodology we used is constructed on a scoring method, aimed at analysing CSR related information, within integrated reports. This method highlights how CSR is disclosed in integrated reporting as part of a strategic approach to CSR. Furthermore, this aims at enhancing the quality and accuracy of the information provided about CSR programs within integrated reports.
\end{abstract}

KEYWORDS: Corporate Social Responsibility, CSR disclosure, Integrated Reporting

JEL CLASSIFICATION: G24, M14

\section{INTRODUCTION}

Integrated reporting increases the vast spectrum of information for all stakeholders, while disclosing financial and non-financial aspects simultaneously, having also a strong connection with CSR corporate social responsibility strategies and initiatives. In the current economic and social environment, especially with the recent health challenges generated by a global pandemic, we consider that there is a growing need for authenticity in the way business organizations interact with their stakeholders. The concept of CSR has the potential of providing this much-needed authenticity but the challenge is how to understand and implement CSR in a proper manner, as a part of a new more sustainable business model and not just part of a PR exercise or a charitable initiative.

CSR has been a constant topic of study for researchers and scholars as well as for managers and non-governmental entities in recent decades. Conceptually formalized in the 1950s by Bowen, CSR refers to "the obligations of businessmen to pursue those policies, to make those decisions, or to

\footnotetext{
${ }^{1}$ West University of Timisoara, Faculty of Business and Adminsitration, Romania, bianca.baditoiu@e-uvt.ro

${ }^{2}$ West University of Timisoara, Faculty of Business and Adminsitration, Romania, alexandru.buglea@e-uvt.ro

${ }^{3}$ West University of Timisoara, Faculty of Business and Adminsitration, Romania, diana.gligor@e-uvt.ro

${ }^{4}$ West University of Timisoara, Faculty of Business and Adminsitration, Romania, valentin.munteanu@e-uvt.ro
} 
follow those lines of action which are desirable in terms of the objectives and values of our society" (Bowen, 1953), even if its existence appears to be as ancient as business itself (Feramosca, Verona, 2019). A historical analysis of how to consider the social role of corporations leads to the identification of three perspectives (Van Marrewijk, 2003): the shareholder approach, or the classical view on CSR, according to which "the social responsibility of business is to increase its profits" (Friedman, 1970), the stakeholder approach, which considers that organizations should comprise a diversity of stakeholders interests that can influence or are influenced by the organization's actions and objectives (Freeman, 1984), and the societal approach, according to which organizations are responsible to the society, of which they are an integral part (CED, 1971). The literature addressing CSR is extremely rich, with studies ranging from analyses of CSR definitions and framework (Caroll, 1999; Van Marrewijk, 2003; Dahlrud, 2008) to analyses of its dimensions (Rahman, 2011; González-Rodríguez et al., 2015; Capelle - Blancard \& Petit, 2017) or the typology of programs and their approach (traditional or strategic) (Pirsch et al., 2007; GligorCimpoieru and Munteanu, 2015; Remund and Keever, 2018). However, both in the corporate and academic environment, the concept of CSR continues to be intensely debated, reconsidered, refined and even challenged. Regardless of what definition we consider or which analysis frame we apply, it is obvious that the appearance, evolution and taxonomic differentiation of the implemented programs are based on the necessity of addressing issues such as: the magnitude of a corporation's role in society, the way in which it can contribute positively to the evolution of society, apart from the commercial activities that represent their scope of activity, or if the multiplication of the corporative senses is justifiable from the point of view of shareholders. Starting with Bowen (1953), many CSR definitions were developed by scholars or practitioners based on their social, economic, political and environmental point of views. Thus, various definitions of CSR cover various dimensions such as sustainable economic development, ethical operational practices, ecological issues and environmental protection, stakeholders involvement, improving the quality of life of the citizens, transparency, accountability, fight against corruption, human rights; labour rights, responsible behaviour, moral obligation, corporate responsiveness and corporate citizenship (Rahman, 2011).

The present paper is structured into 4 sections, except for the introduction. Section 2 (Literature Review) deals with the concept of integrated reporting connected to CSR. The following section continues with a description of the methodology (section 3) and with the results and findings (section 4). The paper ends with the conclusions (section 5), recognizing the limitations of the research and the possible future research directions.

\section{LITERATURE REVIEW}

When considering CSR from a strategic point of view, businesses should be more likely to focus on long-term objectives because business organizations, apart from creating an economic value they also have a social and environmental impact, aspects which are comprised within the "triple P bottom line model” (Graafland et al., 2004).

Despite the abundancy of information on CSR, debate still hovers over a number of aspects related to the concept and frequent arguments indicate the necessity of a strategic approach upon CSR implementation.

Starting from the '70s, existing bibliographical references highlight the need for a strategic approach on social initiatives, often mentioning the need for building a correlation between the social initiatives and the main activities of a business organization. For example, Preston and Post (1975) mention that during that period, organizational social initiatives were characterized by a "large number of different, and not always consistent, usages". During the '80s, Murray and Montanary (1986) stated that although management scholars acknowledge the strategic implications that CSR has on business organizations, only some have concentrated on the interdependent and dynamic 
relationships among the firm and the relevant characters from its social environment. Authors Michael Porter and Mark Kramer mentioned the need for a strategic approach of organizational social initiatives as well, underlining the fact that for a very long period, the economic and social objectives of business organizations were regarded as being distinct and opposite. In fact, according to them, this is a "false dichotomy" as the social and the economic objectives are not conflicting matters but connecting ones. According to this perspective, a strategic approach to organizational social involvement can be achieved only when the social and the economic benefits generated by the social initiative converge. Analysing the relationship between competitive advantages and social responsibility Porter and Kramer underlined in an article from 2006 that the dominant approaches to social responsibility are often fragmented and disconnected from the business, posing a threat for the great opportunities that could emerge. The authors emphasized the fact that when social initiatives are managed as central and not peripheral business choices, business organizations might benefit from substantial, long term advantages, based on the fact that in the present economic and social context, economic achievements and social prosperity are no longer perceived as being part of a zero-sum game. Their article published in 2011 mentions the benefits of the concept of share value creation stating that businesses should no longer focus on creating value only for the owners but also for their organizational stakeholders through "shared value initiatives". According to Porter and Kramer's point of view, there is a need for a new approach on capitalism, because increasing businesses are perceived as a main cause for social, environmental, and economic issues and that they are thriving on the backs of the community. Regrettably, the current legitimacy of business in local communities and in society is perceived publicly to be at the lowest levels in recent history. In this context, in which many companies are blocked on the idea of social responsibility that regards the position of society issues to be peripheral rather than central. In this case, the organizational social initiative might not be of any help. Sometimes, the more a business organization strives to implement corporate responsibility "the more it is accused for society's failures" (Porter and Karmer, 2002).

Philip Kotler and Nancy Lee (2005), apart from describing the six types of CSR programs, also had a substantial contribution in underlining the significance of having a strategic approach to CSR and in highlighting the essential characteristics of the strategic approach to CSR versus the traditional approach of CSR. During the same year, Deborah Doane also criticized the characteristics of traditional approach to CSR, describing CSR as the "friendly face of capitalism" designed for the generation that felt that big business was in fact in charge of the world, leaving the people and the environment aside (Doane, 2005). She firmly disapproved of certain corporate activities associated with CSR programs, which were perceived as a partnership with the "enemy". Doane concluded that corporate social initiatives may induce optimistic thoughts in some people and that CSR is nothing else than placebo giving us a false impression of security and that CSR is effective only if it determines true alteration in the business practices. She also considers legislation to be the only appropriate measure in order to control businesses conducts.

McBarnet, Voiculescu and Campbell (2009) underlined the idea that the current perception of CSR is due to several highly mediatized cases of corporate misconduct, being seen not only as a way of addressing social and environmental issues, but it also targets the essence of the economic activity. Ghalib and Agupusi (2011) described CSR "as a tactical contrivance devised to make business decisions in the corporate world”. Werther and Chandler (2011) also support the need of companies to "undertake a strategic approach to CSR" considering CSR as a part of corporate initiatives that go further than the "nice-to-have extras of corporate philanthropy". These authors define "strategic CSR" as a "a holistic CSR perspective" within the firm's "strategic planning and core operations".

Yuan, Bao and Verbeke (2011) analysed the issue of integrating new CSR initiatives and the existing ones, around a core - periphery thesis. They considered that new CSR programs should "fit" internally ("in terms of expected internal coherence, consistency with prevailing business routines and 
resulting contribution to business performance") and externally (with "societal stakeholder demands for particular CSR activities”).

Perez-Batres et al. (2012) observed that sometimes business organizations use CSR only to create confusion among stakeholders bragging about some sort of social and environmental realizations (doings called greenwashing) to distract their attention from the severe problems generated by them. The authors make a distinction between "symbolic" CSR initiatives and the CSR initiatives of businesses that have truly committed to a positive change in the way they obtain their profit, the "substantial” CSR.

Rangan, Chase and Karim (2015) noticed the increasing pressure put on CSR initiatives to "deliver business goals results", but these authors do not find this perspective to be the best one. In their view this is too much to ask from CSR, distracting CSR programs from their main goal at the same time, namely: the alignment of a company's social and environmental activities with its business purpose and values.

Recently, Vishwanathan et al. (2020) defined the concept of strategic CSR as "those firm activities that appear to further some social good, while at the same time benefitting the firm financially by either enhancing its reputation, increasing stakeholder reciprocation, mitigating firm-specific risk, and/or improving innovation”.

Regarding the focus of this article, namely the level of disclosure of CSR information within integrated reports of financial companies, several aspects need to be taken into consideration when scrutinizing the relationship between CSR and integrated reporting. The concept of integrated reporting (IR) regards the disclosure of information about the achievements (performance) and risks of a company, environmental and corporate governance aspects and the future opportunities and prospects of a company. Publication of One Report (Eccles and Krzus, 2010) also offers a more comprehensive image of the business, "including future targets and links between financial performance and reporting on corporate social and environmental responsibility” (Jensen and Berg, 2012). Implemented by the International Integrated Reporting Council (IIRC), the concept of integrated reporting disclose “the material information about an organisation's strategy, governance, performance and prospects in a way that reflects the commercial, social and environmental context within which it operates." It reveals "a clear and concise representation of how an organisation demonstrates stewards and how it creates and sustains value” (Towards Integrated Reporting, 2011, 2). Briefly, integrated reporting is an attempt of providing a comprehensive understanding of a company's strategy. Rupley et al. (2017) examines the transformation of corporate reporting starting with financial statements and stand-alone corporate social responsibility reports to integrated reports (IR).

According to the legitimacy theory, firms reveal information to their stakeholders with the purpose to meet society's expectations (Ashforth \& Gibbs, 1990). The former custom that required companies to disclose only past financial information to their stakeholders has changed. Despite the costs implied by collection and reporting, it has become a frequent and beneficial practice for organizations to reveal information reflecting non- financial aspects in order to keep clients, customers and other stakeholders satisfied. Stakeholders require lately transparency, responsibility, and strategic information linking the past and future risks and opportunities (information that is commonly not disclosed within traditional financial reporting). In some countries such as Denmark (Frost, 2007), Norway, France (Husser et al., 2012; Morris \& Baddache, 2012), and the United Kingdom, latest legislation requires specific aspects regarding the CSR disclosures (Tschopp \& Huefner, 2015).

Thus, there is proof regarding the growing importance for companies and their management to share and disclose CSR information to shareholders and regulators as a starting point for informed strategic decision-making. Previous research demonstrated that enhanced disclosure, especially disclosures regarding CSR information, is beneficial with respect to the economic interest of companies. Different studies (Hefflin et al., 2011; Fogel et al., 2015) have shown that enhanced disclosure is profitable for companies, resulting in higher credit ratings and positive capital market reaction to 
disclosure regulations. Researchers stated that standards that aim to eliminate or reduce the disclosure of information deprive capital market of relevant information with respect to the value it can generate (Bauman, 2013; Chakrabarty \& Shaw, 2012; Behn et al., 2011).

Lower firm risk (Orlitzky \& Benjamin, 2001; Orlitzky et al., 2003), lower cost of equity (Dhaliwal et al., 2011; Plumlee et al., 2015), lower cost of debt (Bauer \& Hann, 2010; Goss \& Roberts, 2009), higher credit ratings (Bauer \& Hann, 2010), increased stock market performance during times of financial crisis (Lins et al., 2017), and other optimistic analyst recommendations (Ioannou \& Serafein, 2010) are all beneficial aspects related to voluntary CSR information reports. Several studies focus on the link between CSR disclosure and environmental performance (de Villiers \& van Staden, 2011; Ashcroft \& Smith, 2008); governance concepts (Haniffa \& Cooke, 2005; Rupley et al., 2012); and public shareholders (Cormier \& Magnan, 1997; 2003).

On the other hand, there are studies that highlight the existence of CSR and Sustainability aspects in the Integrated Reporting Framework, with focus on the most significant set of voluntary reporting initiatives in the CSR, Sustainability and IR area (Idowu et al., 2016). They developed a comparison analysis with the aim of identifying whether IR could contribute to a "common ground for the nonfinancial reporting frameworks and guidelines". The authors aim to qualitatively analyse the content of the Integrated Reporting Framework, ISO 26000 and the Sustainability Reporting Guidelines G4 and highlight the connections between the framework-standard-guidelines, while trying to find an answer to whether IR can be the solution to the need of having a unique framework that could serve as support for non-financial reporting.

According to the findings of their analysis, most terms, definitions and principles from ISO 26000 and GRI G4 are included in the IR Framework offering a superior understanding of the way in which companies should report and how the revealed information should look like in the annual corporate report. In addition, the chronological sequence of the three frameworks (ISO/GRI/IR) coincides with the improvement in communication with report preparers, so that the guidelines/ standards/ frameworks are better explained. They also state that the future corporate reporting norm in the form of integrated reporting is a result of CSR and sustainability interaction initiatives (Idowu et al., 2016). According to the evidence they found in the literature review and the findings of the comparative analysis, ISO 26000, GRI G4, and the IR Framework are strongly interrelated, representing an evolution of the corporate reporting trend.

Other authors (Wilburn K. \& Wilburn H., 2016) find that an 'Integrative reporting platform' with third-party assessors is essential to achieve clear evaluations of the CSR performance. They state that integrative reports will allow regulators, investors, and consumers to have metrics that are applicable for all industries and which allow comparisons of the CSR objectives and outcomes. It will also impede greenwashing and promoting goals and objectives without data to support achievements. They emphasize the need for a new focus on reporting, while exemplifying the falsely reported facts of the Volkswagen case, within one CSR area that is actually regulated and standardized, namely sustainability and emissions. Since the consumers are increasingly demanding accurate reporting in order to serve them in the decision-making process (based on CSR commitment), reporting must change from being voluntary and additional to becoming a significant part of the business strategy.

Garcia et al. (2015) study why companies are elaborating integrated reporting, focusing on the connection with the CSR report. According to their results, the probability of publishing an integrated report is positively related with the following elements: having the CSR report guaranteed, the year, size and supplement industry. This paper investigated the interest of companies in producing IRs, through the analysis of corporate variables, which could be connected with the disclosure of IRs. The study investigates the importance of Integrated Reporting, based on 7144 observations, according to the GRI database, during the period 2009-2011. Thus, $16.2 \%$ of the analysed companies chose to disclose the stand-alone report, including financial and non-financial information. 20.5\% companies, which disclose their integrated reporting, also offer the CSR reports. Most companies (65 \%) seek the help of a consultant firm to produce CSR reports, while $35 \%$ hire an auditing firm. Their results 
reveal that the probability of presenting an Integrated Report is positively related with having CSR reports assured, with different years, with the company's size and with whether or not it follows the GRI supplement industry. However, they are not associated to whether the guarantee has been provided with the help of an auditor or consultant.

\section{METHODOLOGY}

The integrated report has been described by the IIRC as "a concise communication about how an organization's strategy, governance, performance and prospects, in the context of its external environment, lead to the creation of value over the short, medium and long term” (IIRC, 2013, 8). Starting from the perspective of value creation, while linking it with the strategic aspects of a company and prior literature studies (Cohen et al., 2011; Bădițoiu, 2019; Bădițoiu et al., 2020), this study identifies relative ratings of corporate social responsibility information disclosures within 2019 integrated reports of 16 European financial companies, and uses them to identify the quality of integrated reports with respect to this subject.

Cohen et al. (2011) offer a primary perspective on integrated reporting, describing the extent to which voluntary disclosures within U.S. companies reports, encounter the needs of investors. They conducted a study with 750 retail investors, trying to find out which forms of non-financial information (economic, governance, and social) they use and would like to use in the future and also established relative ratings of non- financial indicators (economic, governance, and social indicators). Using these ratings, the integrated reports of eight U.S. companies were analysed, in order to figure whether the identified information was of great importance for investment decisions. Results demonstrate that the current integrated reports do not provide the expected information identified as important. This study offers the starting point for companies that are preparing IRs and for regulators with respect to a possible future disclosure regulation. Further, Băditoiu (2019) qualitatively analysed the content found in 2018 integrated reports of financial companies with respect to one of the six principles of integrated reporting, namely the "stakeholder relationships" principle. The author finds that the content within integrated reports and the quality of the information disclosure with respect to the stakeholders of a company are not associated with the length or format of the integrated reports and that these qualitative disclosures can ensure many benefits for both the companies and their stakeholders. A similar study conducted by Bădițoiu et al. (2020), focuses on the corporate governance information disclosures within integrated reports, revealing that there are no significant differentiations between the corporate governance disclosures of European and African companies, despite the fact that the European companies are not pressured by any legislation changes regarding the reporting norms, while integrated reports are being mandated for African companies listed on the Johannesburg Stock Exchange.

The present paper focuses on the main topics presented in 2019 annual integrated reports of European companies that reflect the CSR initiatives implemented by the reporting business organizations. Further, we will present the created indicators we used for the qualitative analysis of the 16 financial companies.

For the traditional approach of CSR programs, we verified the following topics:

- Donations - in the form of providing products, services, cash, or intangible assets for different individuals and entities (Hess et al., 2002).

- Sponsorship - has been defined as "an exchange between a sponsor and a sponsored entity (also called property), whereby the sponsor invests in cash and or in kind in a property" (Plewa, \& Quester, 2011). In other words, it means the act of supporting a person, organization, or activity by giving money, encouragement, or other help (Cambridge dictionary).

- Volunteering activities - are defined as "a commitment by a commercial organization to encourage staff to volunteer in the not-for-profit sector” (Plewa \& Quester, 2011). 
- Environmental volunteering and actions - a commitment by an organization to encourage staff to volunteer for environmental and ecological actions, such as: foresting, biodiversity conservations, cleaning natural areas, recycling activities, etc.

Regarding the strategic approach of CSR, we divided the topics into three main aspects:

I. Sustainability\& Environment:

- Sustainable business practices - redesigning the core activities of a business organization in order to achieve the so called "Triple Bottom Line", according to which organizations should simultaneously focus on financial, social and ecological prosperity (Elkington, 1998).

- Sustainable and responsible \& green investments - investments in projects, processes and technologies focused on climate change, resources efficiency and green issues. Related terms refer to SRI (Socially Responsible Investment) or ESG (environmental, social and governance investments) (Inderst et al., 2012).

- Circular/ sharing economy - according to the World Economic Forum, a Circular economy is "an industrial system that is restorative or regenerative by intention and design". This system "replaces the end-of-life concept with restoration" and makes several shifts towards the use of renewable energy (World Economic Forum).

- Transition to a low carbon economy/ addressing climate change - identifying and reducing carbon emissions and climate related risks, within the entire value chain.

II. Community:

- Reducing inequalities/poverty and promoting social inclusion - the systemic deployment of actions addressing poverty and social inequalities issues in operating communities and territories.

- Woman empowerment - systemic reinforcement of gender emancipation issues (i.e. woman entrepreneurship, woman social initiatives, woman public representation) in operating communities and territories.

- Minorities inclusion \& diversity - inclusion of people with diverse traits linked to gender, age, origin, ethnic group, religious belief, sexual orientation and disability conditions.

- Respect for human rights - ensuring that fundamental human rights, such as dignity, fairness, equality, respect and independence, and the prevention of forced child labour, are respected throughout the entire value chain (suppliers, subcontractors, business partners).

- Anti-corruption \& bribery matters - maintaining clear and consistent policies, through which there is zero tolerance for corruption and bribery throughout the entire value chain, both at organizational and individual level.

- Sustaining healthcare needs and services - systematic support of initiatives, in order to improve the access and quality of public and private healthcare services in operating communities and territories.

- Stakeholder dialogue - development of partnerships in different sectors, based on effective communication platforms, to share knowledge and identify systematic solutions (Assicurazioni Generali, 21).

- Evolving lifestyle and consumption patterns - the enhancing awareness of the connection between the health and living habits with the impact on the natural environmental.

III. Employees:

- Training \& education programs - continuously investments in the development of employees' skills and competencies, through professional and cultural programs.

- Gender balance - ensuring equal participation of women and men in all work areas (equal pay for equivalent work, recruitment and promotion processes, training and mentoring programs, work-life balance and company culture) and projects or programs (European Institute for Gender Equality). 
- Minorities Inclusion - balanced participation of all minorities, proving the employee's diversity linked to gender, age, origin, ethnic group, religious belief, sexual orientation and disability conditions in all work areas.

- Employee's engagement and well-being measures \& surveys - constant engagement for proving and measuring the wellbeing of the employees, as a key factor for organizational attainment.

\section{FINDINGS AND RESULTS}

After we qualitatively analysed 2019 integrated reports of 16 European financial companies, while looking for the previous detailed topics (see Methodology) connected to their CSR activities and scoring the present information with one point and the lack of information with zero points, we obtained while running descriptive statistics, the following indicators: Mean, Standard Error, Median, Mode, Standard Deviation, Sample Variance, Kurtosis, Skewness, Range, Minimum, Maximum, Sum and Count. Additionally, we calculated the coefficient of variation. Some indicators (Kurtosis and Skewness) could not be calculated for the companies with identical data information. We eliminated Minimum and Maximum, due to irrelevance because of the scoring method.

Table 1. CSR disclosures of European companies

\begin{tabular}{|c|c|c|c|c|c|c|c|c|c|c|c|c|}
\hline Company & Mean & $\begin{array}{l}\text { Standard } \\
\text { Error }\end{array}$ & Median & Mode & $\begin{array}{l}\text { Standard } \\
\text { Deviation }\end{array}$ & $\begin{array}{l}\text { Sample } \\
\text { Variance }\end{array}$ & Kurtosis & Skewness & Range & Sum & Count & $\begin{array}{c}\text { Coefficient } \\
\text { of variation }\end{array}$ \\
\hline $\begin{array}{l}\text { ASSICURAZIONI } \\
\text { GENERALI }\end{array}$ & 0.95 & 0.05 & 1 & 1 & 0.22 & 0.05 & 20 & -4.472 & 1 & 19 & 20 & 0.24 \\
\hline$A X A$ & 0.75 & 0.10 & 1 & 1 & 0.44 & 0.20 & -0.497 & -1.251 & 1 & 15 & 20 & 0.59 \\
\hline $\begin{array}{l}\text { BANCA POPULAR } \\
\text { ESPANOL }\end{array}$ & 1.00 & 0.00 & 1 & 1 & 0.00 & 0.00 & $\begin{array}{c}\# \mathrm{DIV} / 0 \\
!\end{array}$ & $\begin{array}{c}\text { \#DIV/0 } \\
\quad !\end{array}$ & 0 & 20 & 20 & 0.00 \\
\hline CAIXA BANK & 1.00 & 0.00 & 1 & 1 & 0.00 & 0.00 & $\begin{array}{c}\text { \#DIV/0 } \\
!\end{array}$ & $\begin{array}{c}\text { \#DIV/0 } \\
!\end{array}$ & 0 & 20 & 20 & 0.00 \\
\hline DIRECT LINE & 0.95 & 0.05 & 1 & 1 & 0.22 & 0.05 & 20 & -4.472 & 1 & 19 & 20 & 0.24 \\
\hline FIDEURAM & 0.85 & 0.08 & 1 & 1 & 0.37 & 0.13 & 2.776 & -2.123 & 1 & 17 & 20 & 0.43 \\
\hline RBS & 0.80 & 0.09 & 1 & 1 & 0.41 & 0.17 & 0.699 & -1.624 & 1 & 16 & 20 & 0.51 \\
\hline RSA INSURANCE & 0.75 & 0.10 & 1 & 1 & 0.44 & 0.20 & -0.497 & -1.251 & 1 & 15 & 20 & 0.59 \\
\hline $\begin{array}{c}\text { SAUDI } \\
\text { INVESTEMENT } \\
\text { BANK } \\
\end{array}$ & 0.95 & 0.05 & 1 & 1 & 0.22 & 0.05 & 20 & -4.472 & 1 & 19 & 20 & 0.24 \\
\hline UNICREDIT & 0.80 & 0.09 & 1 & 1 & 0.41 & 0.17 & 0.699 & -1.624 & 1 & 16 & 20 & 0.51 \\
\hline UNIPOL & 0.80 & 0.09 & 1 & 1 & 0.41 & 0.17 & 0.699 & -1.624 & 1 & 16 & 20 & 0.51 \\
\hline FMO & 0.75 & 0.10 & 1 & 1 & 0.44 & 0.20 & -0.497 & -1.251 & 1 & 15 & 20 & 0.59 \\
\hline GARANTI BANK & 0.80 & 0.09 & 1 & 1 & 0.41 & 0.17 & 0.699 & -1.624 & 1 & 16 & 20 & 0.51 \\
\hline HSBC & 0.75 & 0.10 & 1 & 1 & 0.44 & 0.20 & -0.497 & -1.251 & 1 & 15 & 20 & 0.59 \\
\hline ING & 0.75 & 0.10 & 1 & 1 & 0.44 & 0.20 & -0.497 & -1.251 & 1 & 15 & 20 & 0.59 \\
\hline $\begin{array}{c}\text { LLOYDS } \\
\text { BANKING } \\
\end{array}$ & 0.90 & 0.07 & 1 & 1 & 0.31 & 0.09 & 7.037 & -2.888 & 1 & 18 & 20 & 0.34 \\
\hline
\end{tabular}

Source: own construction

For Assicurazioni Generali, Direct Line Group and Saudi Investment Bank most of the analysed data (95\%) received the value one, whereas only $5 \%$ of the data received the value 0 . The coefficient of variation $<35 \%$, thus indicating homogeneity among the analysed companies, most of its values being 1 . The Kurtosis of 20 confirms the agglomeration around a singular value (i.e. 1), a 
value confirmed also by the mode. The negative asymmetry shows the bending of the distribution curve to the right and the elongation to the left, towards the few zero values. Therefore, the three mentioned companies present homogeneity in fulfilling the analysed indicators, presenting a high degree of fulfilment. Lloyds Banking is in a similar situation, revealing most of the analysed information ( $90 \%$ of the data received the value 1 , whereas $10 \%$ received the value 0 ). The coefficient of variation $<35 \%$, thus indicating homogeneity among the analysed companies, most of its values being 1 . The Kurtosis of 7.03 confirms the agglomeration around a singular value (i.e. 1), a value confirmed also by the mode. Thus, Lloyds Banking presents homogeneity in fulfilling the analysed indicators, presenting a high degree of fulfilment.

Axa, RSA Insurance, FMO, HSBC and ING Bank find themselves in a different situation. 75\% of the data have a value of 1 , whereas $25 \%$ of the data have a value of $0.35 \%<$ coefficient of variation $<70 \%$, thus resulting that the indicator does not show homogeneity among the analysed companies, and that most of its values are 1 . The Kurtosis of -0.49 confirms the lack of agglomeration of most values around a single value. The negative asymmetry shows the bending of the distribution curve to the right and the elongation to the left, towards the few zero values. Therefore, the companies AXA, RSA Insurance, FMO, HSBC and ING Bank do not present homogeneity in fulfilling the analysed indicators, presenting a moderate degree of fulfilment.

Banca Popular Espanol and Caixa Bank offered information about all analysed topics regarding their CSR programs, thus $100 \%$ of the analysed topics received the value 1 .

For RBS, Unicredit, Unipol and Garanti Bank, $80 \%$ of the analysed data received the value 1, whereas $20 \%$ of the data received the value 0 . $35 \%<$ coefficient of variation $<70 \%$, thus resulting that the indicator does not show homogeneity among the analysed companies, and that most of its values are 1 . The Kurtosis of 0.69 confirms the agglomeration around a singular value (i.e. 1), a value confirmed also by the mode. The negative asymmetry shows the bending of the distribution curve to the right and the elongation to the left, towards the few zero values. Therefore, the companies RBS, Unicredit, Unipol and Garanti Bank do not present homogeneity in fulfilling the analysed indicators, presenting a moderate degree of fulfilment. In the similar case of Fideuram, $85 \%$ of the analysed data received the value 1 , whereas $15 \%$ received the value $0.35 \%<$ coefficient of variation $<70 \%$, thus resulting that the indicator does not show homogeneity among the analysed companies, and that most of its values are 1. The Kurtosis of 2.77 confirms the agglomeration around a singular value (i.e. 1), a value confirmed also by the mode. The negative asymmetry shows the bending of the distribution curve to the right and the elongation to the left, towards the few zero values. Similarly, Fideuram presents a moderate degree of fulfilment of the analysed indicators.

Table 2. Disclosures regarding the traditional approach of CSR

\begin{tabular}{|c|c|c|c|}
\hline Indicators regarding the traditional approach of CSR & Mean & Sum & Count \\
\hline Sponsorship & 0.9375 & 15 & 16 \\
\hline Donations/corporate giving & 0.8750 & 14 & 16 \\
\hline Social volunteering activities & 0.7500 & 12 & 16 \\
\hline Environmental volunteering \& actions & 0.625 & 10 & 16 \\
\hline
\end{tabular}

Source: own construction

Regarding the traditional approach of CSR, 15 out 16 companies revealed information about their sponsorship activities (93,75\% of the data have the value 1 , whereas $6,25 \%$ have the value 0 ), 14 
out of 16 companies shared details about donations or corporate giving (87,5\% of the data have the value 1 , whereas $12,5 \%$ have the value 0 ), 12 out 16 companies described their social volunteering activities ( $75 \%$ of the data have the value 1 , whereas $25 \%$ of the data have the value 0 ) and only 10 out of 16 companies shared details regarding their commitment to environmental volunteering (62,5\% of the data received the value 1 , whereas $37,5 \%$ have the value 0 ).

Table 3. Disclosures regarding the strategic approach of CSR

\begin{tabular}{|c|c|c|c|c|c|}
\hline & \\
\hline & & Indicators & Mean & Sum & Count \\
\hline \multirow{16}{*}{$\begin{array}{l}\text { Strategic approach of } \\
\text { CSR }\end{array}$} & \multirow{4}{*}{$\begin{array}{l}\text { Sustainability \& } \\
\text { Environment }\end{array}$} & $\begin{array}{c}\text { Sustainable business practices (i.e. increased security, } \\
\text { transparency) }\end{array}$ & 1 & 16 & 16 \\
\hline & & Sustainable and responsible \& green investments & 1 & 16 & 16 \\
\hline & & Circular/sharing economy & 0.5 & 8 & 16 \\
\hline & & $\begin{array}{c}\text { Transition to a low carbon economy/ addressing climate } \\
\text { change }\end{array}$ & 1 & 16 & 16 \\
\hline & \multirow{8}{*}{ Community } & Reducing inequalities/poverty and promoting social inclusion & 0.875 & 14 & 16 \\
\hline & & $\begin{array}{c}\text { Woman empowerment \& emancipation/woman } \\
\text { entrepreneurship }\end{array}$ & 0.6875 & 11 & 16 \\
\hline & & Minorities inclusion \& diversity & 0.5 & 8 & 16 \\
\hline & & Respect for human rights & 0.9375 & 15 & 16 \\
\hline & & Anti-corruption \& bribery matters & 0.9375 & 15 & 16 \\
\hline & & Sustaining healthcare needs and services & 0.625 & 10 & 16 \\
\hline & & Stakeholder dialogue & 1 & 16 & 16 \\
\hline & & Evolving lifestyle and consumption patterns & 0.875 & 14 & 16 \\
\hline & \multirow{4}{*}{ Employees } & Training \& education programs & 1 & 16 & 16 \\
\hline & & Gender balance & 1 & 16 & 16 \\
\hline & & Minorities inclusion & 0.8125 & 13 & 16 \\
\hline & & Employee's engagement and well-being measures \& surveys & 1 & 16 & 16 \\
\hline
\end{tabular}

Source: own construction

With respect to the strategic approach of CSR, regarding sustainability and environment actions all companies shared information about their sustainable business practices, sustainable and responsible and green investments, and the transition to a low carbon economy, including issued related to climate change. Regarding the circular/ sharing economy, only half of them revealed such aspects.

With respect to the community, 14 out of 16 companies shared details about programs through which they address inequalities/poverty and also promote social inclusion and an evolving lifestyle and consumption patterns, 11 out of 16 companies revealed information about Woman empowerment, half of them address issues related to minorities inclusion and diversity, 15 out of 16 revealed information about the respect for human rights and their anti-corruption and bribery matters, 10 out of 16 companies shared information on how they sustain the healthcare needs and services and all companies shared information regarding their dialogue with stakeholders.

Addressing employees CSR programs, all companies shared information about the training and education programs, the gender balance between employees and their employee's engagement, well-being measures and surveys they implement. With respect to the minorities inclusion of the employees, only 13 out of 16 companies, revealed information. 


\section{CONCLUSIONS}

An important contribution of our paper is represented by the identification of the criteria linking the CSR disclosure with integrated reporting. We have identified the main topics reflecting the CSR activities of a business organization that are present in annual integrated reports (detailed in the section of the paper dedicated to presenting the used research methodology). We underlined the fact that implementing CSR in a traditional approach, purely philanthropic and for the image benefit, and not in a strategic approach, with long term measurable results, could actually be harmful for business organizations.

Furthermore, we observed that there is a great openness towards the strategic approach of CSR within the IR of companies from the banking and insurances sectors. Our main findings suggest that the majority of the European financial companies that disclose annual integrated reports include in these reports mainly their strategic CSR initiatives, with limited disclosure in annual reports of the traditional CSR initiatives.

More specific, regarding the traditional approach of CSR, we observed that the foremost information disclosed by the analysed companies was connected with their donations, followed by information about their sponsorship activities, and by their social volunteering activities. Among the traditional approach of CSR, the least revealed information regarded the volunteering actions for environmental and ecological aspects.

With respect to the strategic approach of CSR, for sustainability and environment, the focus of the companies was on the following topics: sustainable business practices, sustainable investments, responsible and green investments and the transition to a low carbon economy, addressing also issues related to climate change. We observed that the aspects concerning a circular/sharing economy were the least disclosed aspects within integrated reports. The main focus regarding community issues was related to the dialogue of the analysed companies with their stakeholders, followed by issues connected with the respect for human right and anti-corruption and bribery matters. The least revealed information regarded topics connected to the inclusion of minorities and increasing of the diversity within communities followed by sustaining healthcare needs and services. The strategic approach of CSR regarding the employees was mostly revealed throughout information about training and education programs of employees, the gender balance and the employee's engagement and different well-being measures.

Banca Popular Espanol and Caixa Bank reported the most information regarding their CSR activities (all indicators analysed were disclosed), followed by Assicurazioni Generali, Direct Line Group ,Saudi Investment Bank (95\% of the analysed topics were detailed) and by Lloyds Banking (90\% of the analysed indicators were shared).

Fideuram (with $85 \%$ of information disclosed), followed by RBS, Unicredit, Unipol and Garanti Bank (where $80 \%$ of information was disclosed) find themselves in the middle of the ranking, with some information and Axa, RSA Insurance, FMO, HSBC and ING Bank are at the bottom of the rank, with the least revealed information (75\% of all indicators were described).

One of the main limitations of our research is associated with the small number of companies taken into consideration in the study (16 companies), thus making the available database quite limited. Aditionally, the study is restricted to a single continent, namely Europe, and to only two comparable sectors (financial and insurances sector).

The integrated reports analysed in our study differ in both complexity and content volume, as well as in terms of data presentation. It is challenging to compare the information within those reports and in agreement with other authors, such as Chaidali and Jones (2017), we also consider these report length and format to be problematic. The methodology could also be included here, because of the subjectivity associated with the scoring process.

Nonetheless, despite limitations, this paper discloses important information about the content of integrated reports and about information quality regarding the CSR disclosures of 16 European 
companies. It also offers insight regarding an important connection between the strategic approach of CSR and integrated reporting.

Further research could analyse the impact of the current global pandemic on the way CSR activities of financial and insurance companies are disclosed in annual integrated reports and compare them with our current results, presented in this paper. Another further research direction could address the idea of comparing integrated reports of companies within different sectors with respect to their CSR disclosures.

\section{REFERENCES}

Ashcroft, P., \& Smith, L. M. (2008), Impact of Environmental Regulation on Financial Reporting of Pollution Activity: A Comparative Study of U.S. and Canadian Firms. Research in Accounting Regulation, 20, 127-153, Available at SSRN: https://ssrn.com/abstract=1029175.

Ashforth, B., \& Gibbs, B. (1990). The double-edge of organizational legitimation. Organization Science, 1, 177-194.

Bădițoiu, B. R. (2019). The Integrated Reporting "Stakeholder Relationships" Principle in the European Financial Sector. Paper presented at the 15th Annual International Bata Conference for Ph.D. Students and Young Researchers (Vol. 15). Zlín: Tomas Bata University in Zlín, Faculty of Management and Economics. Retrieved from http://dokbat.utb.cz/conferenceproceedings/ ISBN: 978-80-7454-893-2.

Bădițoiu, B. R., Buglea, A., Munteanu, V. P., (2020). Corporate Governance in the Context of Integrated Reporting. Review of International Comparative Management, 21(3), 332-343.

Bauer, R., \& Hann, D. (2010). Corporate environmental management and credit risk. Maastricht University. Unpublished Working paper.

Bauman, M. (2013). The adequacy of fixed asset disclosures under U.S. GAAP. Research in Accounting Regulation, 25 (2), 149-156.

Behn, B., Riley, R., Gotti, G., \& Brooks, R. (2011). Discontinued SEC required disclosures: The value of repairs and maintenance expenses. Research in Accounting Regulation, 23 (2), 184187.

Bowen, H. R. (1953). Social responsibilities of the businessman. New York: Harper \& Row.

Capelle-Blancard, G., \& Petit, A. (2017). The weighting of CSR dimensions: One size does not fit all. Business \& Society, 56(6), 919-943.

Carroll, A. B. (1999). Corporate social responsibility: Evolution of a definitional construct. Business \& society, 38(3), 268-295.

Chaidali, P. \& Jones, M.J. (2017). It's a matter of trust: Exploring the perceptions of Integrated Reporting preparers [Abstract]. Critical Perspectives on Accounting, Elsevier, 48(C), 1-20.

Chakrabarty, B., \& Shaw, K. (2012). Eliminating the 20-F reconciliation from IFRS to U.S. GAAP: Short-term and long-term liquidity effects. Research in Accounting Regulation, 24 (2), 90-95.

Circular Economy and Material Value Chains. (n.d.) In World Economic Forum Org. Retrieved August 21, 2020, from: https://www.weforum.org/projects/circular-economy

Cohen, J., Holder-Webb, L., Nath, L., and Wood, D. (2011): Retail Investors' Perceptions of the Decision-Usefulness of Economic Performance, Governance, and Corporate Social Responsibility Disclosures. Behavioral Research in Accounting, 23(1), 109-129.

Cormier, D., \& Magnan, M. (1997). Investors' assessment of implicit environmental liabilities: An empirical investigation. Journal of Accounting and Public Policy, 16 (2), 215-241.

Cormier, D., \& Magnan, M. (2003). Environmental reporting management: A continental European perspective. Journal of Accounting and Public Policy, 22 (1), 43-62.

Dahlsrud, A. (2008). How corporate social responsibility is defined: an analysis of 37 definitions. Corporate Social Responsibility and Environmental Management, 15(1), 1-13. 
De Villiers, C. J., \& Van Staden, C. J. (2011). Where firms choose to disclose voluntary environmental information. Journal of Accounting and Public Policy, 30 (6), 504-525.

Dhaliwal, D. S., Li, O. Z., Tsang, A., \& Yang, G. Y. (2011). Voluntary nonfinancial disclosure and the cost of equity capital: The initiation of corporate social responsibility reporting. The Accounting Review, 86 (1), 59-100.

Doane, D. (2005). The Myth of CSR. The problem with assuming that companies can do well while also doing good is that markets don't really work that way,.Stanford Social Innovation Review.

Eccles Rg, Krzus Mp. 2010. One Report. Integrated Reporting for a Sustainable Strategy. John Wiley and Sons: Hoboken, NJ, USA.

Elkington, J. (1998). "Partnerships from cannibals with forks: The triple bottom line of 21st-century business." Environmental quality management. 8(1), 37-51.

Ferramosca, S., \& Verona, R. (2020). Framing the evolution of corporate social responsibility as a discipline (1973-2018): A large-scale scientometric analysis. Corporate Social Responsibility and Environmental Management, 27(1), 178-203.

Fogel, K., El-Khatib, R., Feng, N. C., \& Torres-Spelliscy, C. (2015). Compliance costs and disclosure requirement mandate: Some evidence. Research in Accounting Regulation, 27 (1), 83-87.

Freeman, R. E. (1984), Strategic Management: A Stakeholder Approach. Pitman Publishing Inc., Marshfield.

Friedman, Milton (1970). “The Social Responsibility of Business is to Increase its Profits”, The New York Times Magazine.

Frost, G. F. (2007). The introduction of mandatory environmental guidelines: Australian evidence. Abacus, 43 (2), 190-216.

Ghalib, A. K., Agupusi, P., (2011). How socially responsible are multinational corporations? Perspectives from the developing world, Working Paper 32, DEV Working Paper Series, The School of International Development, University of East Anglia, UK.

Gligor-Cimpoieru, D. C., \& Munteanu, V. P. (2015). CSR Benefits and Costs in a Strategic Approach. Annals of the University of Craiova, Economic Sciences Series, 1.

González-Rodríguez, M. R., Díaz-Fernández, M. C., \& Simonetti, B. (2015). The social, economic and environmental dimensions of corporate social responsibility: The role played by consumers and potential entrepreneurs. International Business Review, 24(5), 836-848.

Goss, A., \& Roberts, G. S. (2009). The impact of corporate social responsibility on the cost of bank loans. Ryerson University Working paper.

Graafland, J.J., Eijffinger, S.C.W. \& SmidJohan, H. (2004). Benchmarking of Corporate Social Responsibility: Methodological Problems and Robustness. Journal of Business Ethics, 53 (1-2), 51-7.

Haniffa, R. M., \& Cooke, T. E. (2005). The impact of culture and governance on corporate social reporting. Journal of Accounting and Public Policy, 24, 391-430.

Hefflin, F., Shaw, K., \& Wild, J. J. (2011). Credit ratings and disclosure channels. Research in Accounting Regulation, 23 (1), 20-33.

Hess, D., Rogovsky, N. and Dunfee, T. W. (2002). The Next Wave of Corporate Community Involvement: Corporate Social Initiatives. California Management Review, 44(2), 110-125.

Husser, J., Jean-Marc, A., Barbat, G., \& Lespinet-Najib, V. (2012). CSR and sustainable development: Are the concepts compatible. Management of Environmental Quality, 23 (6), 658-672.

Idowu, S.O., Dragu, I., Tiron-Tudor, A., Fracas, T.V. (2016), From CSR and Sustainability to Integrated Reporting, International Journal of Entrepreneurship and Innovation, 4 (2), 143151. 
Inderst, G., Kaminker, Ch., Stewart, F. (2012), "Defining and Measuring Green Investments: Implications for Institutional Investors" Asset Allocations", OECD Working Papers on Finance, Insurance and Private Pensions, No.24, OECD Publishing.

Integrated Reporting Examples Database (n.d.), Retrieved August, 20, 2020 from: http://examples.integratedreporting.org/search_reporter? $\mathrm{x}=30 \& \mathrm{y}=26 \&$ organisation_region=1

Ioannou, I., \& Serafeim, G. (2010). The impact of corporate social responsibility on investment recommendations. Harvard University Unpublished Working paper.

Jensen J. C., Berg N. (2012). Determinants of traditional sustainability reporting versus integrated reporting. An institutionalist approach. Business Strategy and Environment, 21, 299-316.

Kotler, P. \& Lee, N. (2005). Corporate Social Responsibility - Doing the Most Good for Your Company and Your Cause, New Jersey: John Wiley \& Sons.

Lins, K. V., Servaes, H., \& Tamayo, A. (2017). Social capital, trust, and firm performance: The value of corporate social responsibility during the financial crisis. Journal of Finance, 72(4), $1785-1824$.

McBarnet D., Voiculescu A., Campbell T. (2009). The New Corporate Accountability: Corporate Social Responsibility and the Law, Cambridge University Press.

Morris, J., \& Baddache, F. (2012). The five W's of France's CSR reporting law. [online] Retrieved from: https://www.bsr.org/reports/The_5_Ws_of_Frances_CSR_Reporting_Law_FINAL.pdf (Accessed: 08 September 2020).

Murray, K.B. \& Montanary, J.R. (1986). Strategic Management of the Socially Responsible Firm: Integrating Management and Marketing Theory. Academy of Management Review, 11(4), 815827.

Orlitzky, M., \& Benjamin, J. D. (2001). Corporate social performance and firm risk: A metaanalytic review. Business and Society, 40 (4), 369-396.

Orlitzky, M., Schmidt, F. L., \& Rynes, S. L. (2003). Corporate social and financial performance: A meta-analysis. Organization Studies, 24 (3), 403-441.

Perez-Batres, L. A., Doh, J., Miller, V. \& Pisani M. J. (2012). Stakeholder Pressures as Determinants of CSR Strategic Choice: Why do Firms Choose Symbolic Versus Substantive Self-Regulatory Codes of Conduct?. Journal of Business Ethics, 110 (2), 157-172.

Pirsch, J., Gupta, S., \& Grau, S. L. (2007). A framework for understanding corporate social responsibility programs as a continuum: An exploratory study. Journal of Business Ethics, 70(2), 125-140.

Plewa, C., \& Quester, P. (2011), "Sponsorship and CSR: Is there a link? A conceptual framework", International Journal of Sports Marketing \& Sponsorship, 12(4), 301-317.

Plumlee, M., Brown, D., \& Marshall, R. S. (2015). Voluntary environmental disclosure quality and firm value: Further evidence. Journal of Accounting and Public Policy, 34 (4), 336-361.

Porter, M. E. \& Kramer, M.R. (2002). The Competitive Advantage of Corporate Philanthropy. Harvard Business Review, 80 (12), 56-69.

Porter, M. E. \& Kramer, M.R. (2006). Strategy \& society: The link between competitive advantage and corporate social responsibility. Harvard Business Review, 84(12), 78-92.

Porter, M., Kramer, M. (2011). Creating Shared Value. Harvard Business Review, 89 (1/2), 62-77.

Preston, L., and Post J. (1975). Private Management and Public Policy: The Principle of Public Responsibility. New Jersey: Prentice Hall.

Rahman, S. (2011). Evaluation of definitions: ten dimensions of corporate social responsibility. World Review of Business Research, 1(1), 166-176.

Rangan, K., Chase, L., \& Karim, S. (2015). The truth about CSR. Harvard Business Review, 93(1/2), 41-49.

Remund, D. L., \& Mckeever, B. W. (2018). Forging effective corporate/nonprofit partnerships for CSR programs. Journal of Communication Management. 
Rupley, K., Brown, D., \& Marshall, R. S. (2012). Governance, media and the quality of environmental disclosure. Journal of Accounting and Public Policy, 31 (6), 610-640.

Rupley, K.H.; Brown, D.; Marshall, S (2017). Evolution of corporate reporting: From stand-alone corporate social responsibility reporting to integrated reporting. Research in Accounting Regulation, 29, 172-176.

Sierra-García, L.; Zorio-Grima, A.; García-Benau, M.A. (2015), Stakeholder engagement, corporate social responsibility and integrated reporting: An exploratory study. Corporate Social Responsibility and Environmental Management, 22, 286-304.

Social Responsibilities of Business Organizations (1971), In Committee For Economic Development, Retrieved August 10, 2020, from: https://www.ced.org/reports/socialresponsibilities-of-business-corporations.

The International $<$ IR $>$ Framework (December, 2013). [PDF file] Retrieved August 18, 2020, from: https://integratedreporting.org/wp-content/uploads/2015/03/13-12-08-THEINTERNATIONAL-IR-FRAMEWORK-2-1.pdf

Towards Integrated Reporting. Communicating Value in the $21^{\text {st }}$ Century. (2011). In Integrated Reporting Org. Retrieved August 20, 2020, from: https://integratedreporting.org/wpcontent/uploads/2011/09/IR-Discussion-Paper-2011_spreads.pdf

Tschopp, D., \& Huefner, R. (2015). Comparing the evolution of CSR reporting to that of financial reporting. Journal of Business Ethics, 127 (3), 565-577.

Van Marrewijk, M. (2003). Concepts and definitions of CSR and corporate sustainability: Between agency and communion. Journal of business ethics, 44(2-3), 95-105.

Vishwanathan, P., Oosterhoutb, H., Heugensb P., Duranc, P., Essend, M. (2020). Strategic CSR: A Concept Building Meta-Analysis. Journal of Management Studies, 57(2).

Werther W. B. Jr., Chandler D., (2011). Strategic Corporate Social Responsibility. Stakeholders in a Global Society. 2 Edition, SAGE Publications Inc.

Wilburn, K. M. \& Wilburn, H. R. (2016). The Growing Importance of Integrated Reporting for Corporate Social Responsibility. Review of Business \& Finance Studies, 7 (2), 75-89.

Yuan, W., Bao, Y., \& Verbeke, A. (2011). Integrating CSR initiatives in business: an organizing framework. Journal of Business Ethics, 101(1), 75-92. 